\title{
The Pharmacological Activity of Some Tamaricaceae Plants
}

Nabila Al-Jaber ${ }^{1^{*}}$ and Lamya Allehaib ${ }^{2}$

${ }^{1}$ Chemistry Department, College of Science, King Saud University, Riyadh, KSA

${ }^{2}$ Chemistry Department, College of Science, Qassim University, KSA

\begin{abstract}
The antipyretic activity of the alcoholic extracts for the Tamarix aucheriana, T. nilotica, and $T$. aphylla were measured in the Wistar albino male rats (150-180 g) by using a yeast-induced hyperpyrexia test. The carrageenan induced paw edema method. The anti-inflammatory activity of the $T$. aucheriana, $T$. nilotica, and $T$. aphylla extracts was measured. The edema was expressed as an increase in paw volume. The analgesic activity of the alcoholic extracts of the $T$. aucheriana, T. nilotica, and T. aphylla were implemented in the Swiss albino mice by using acetic acid induced writhing and hot plate methods.
\end{abstract}

Keywords: Tamarix aucheriana; T. nilotica; T. aphylla; Antipyretic; Anti-inflammatory; Analgesic

\section{Introduction}

Tamaricaceae is a relatively small family containing 4 genera and about 120 species [1]. According to Migahid, there are two genera in Saudi Arabia (Tamarix and Reaumuria) [2]. The genus Tamarix is considered the largest in the family in that it contains about 54 species [3]. There are eight Tamarix species in Saudi Arabia, namely: T. mascatensis Bunge, T. ramosissima Leded, T. nilotica Ehrenb Bunge, T. aphylla L., T. tetragyna Ehrenb, T. aucheriana Decne, T. pyconocarpa DC and T. passerinoides Del [4].

The plants of genus Tamarix contain diverse chemical constituents, including polyphenols, flavonoids, and tannins [5]. In addition to the before mentioned constituents, volatile constituents are also deemed to be among those constituents [6]. The Tamarix species are worth studying not only for the variety of chemical compounds they contain but also for the nature of their biological activity [7].

Several research studies had proved that some Tamarix species showed antioxidant and antimicrobial activities such as T. ramosissima [8], T. aphyla [9,10], and T. gallica [11]. On the other hand, the plants of genus Tamarix are employed in traditional medicine [5].

According to Jaganath and Crozier, phenolic compounds possessed one or more aromatic rings with one or more hydroxyl group [12]. They have been classified into flavonoids and non-flavonoid phenolic compounds. However, tamarixetin was isolated from T. ramosissima and in which it showed significant DNA damaging activity in mutant yeast bioassay [8]. On the other hand, the highly oxygenated bioactive flavone, gardenin B was isolated from the aerial parts of $T$. dioica which showed antiviral activity and anti-invasive activity against solid tumors [13]. The flavonoids isorhamnetin and rhamnocitrin that were isolated from the aerial part of $T$. hispida showed significant inhibitory activity against prolyl endopeptidase (PEP) [14]. Kaempferol 7,4'-dimethyl ether was also isolated from the T. ramosissima and showed a good antioxidant activity as well as a-glucosidase inhibitory action (Xing). Quercetin was isolated from the aerial part of T. nilotica and showed a potent antioxidant activity with $\mathrm{IC}_{50}$ value of $5.72 \mu \mathrm{M}[1]$.

\section{Biological activities}

Several previous studies investigated the role of biological activities and medicinal importance of the genus Tamarix. In this research, a variety of crucial biological activities reported in the literature will be briefly summarized in the subsequent discussion. It was reported that in Asia and Africa, few plants species, which belong to genus Tamarix, are employed in traditional medicine [5]. Generally, Tamarix species are used in traditional medicine as astringent, appetizer, diaphoretic, and diuretic [15]. Furthermore, literature has shown that they are very effective for treating leucoderma, spleen troubles and eye diseases [15]. In southwestern of Saudi Arabia, the leaves of Tamarix species are often wrapped on the head to relieve headache and fever. Moreover, in Dhofar (a region in southern Oman), the decoction of the leaves is given to women to induce labor. The extracts of Tamarix plants have been used in traditional Egyptian medicine as antiseptic agents. In addition, they are used for tanning and dyeing purposes [16]. In Egypt, leaves and young branches of Tamarix plants are cooked to treat oedema of spleen and are mixed with ginger to remedy uterus infections. On the other hand, after being mixed with vinegar, the decoction of the bark is used as a natural remedy for getting rid of head lice [17].

T. aphylla is also employed in traditional medicine in Middle Eastern countries [18]. The bark of T. aphylla is used by people living in the Coastal Mediterranean region of Egypt as astringent, tonic, and effective remedy for treating eczema capitis. Moreover, T. aphylla is used in the Eastern Mediterranean region for treatment of fever and eye inflammation. Furthermore, an extract of powdered leaves of T. aphylla is used to treat toothache. In addition, smoke of burnt leaves can be often equally effective for treatment of wounds [19].

T. nilotica is used in traditional Egyptian medicine as an antiseptic agent. In addition, T. nilotica has been known since pharaonic times and has been used to expel fever, relieve headache, draw out inflammation, and as an aphrodisiac too [20]. In Yemen, an infusion of fresh leaves of T. nilotica is used to treat diarrhea [5].

An extract of T. aphylla showed antioxidant [9], antimicrobial [10], antifungal, anti-inflammatory, and wound healing activities [18]. In addition, the flower extract of $T$. aphylla proved to be a distinct radical scavenging effect in which it improved the viability of human keratinocytes (HaCaT cells) [21]. Furthermore, the aqueous ethanolic extract of the T. aphylla was found to exert an anti-inflammatory activity and antipyretic effect at $20 \mathrm{mg} / \mathrm{kg}$ [22].

An extract of T. nilotica showed a hepatoprotective and antioxidant activity [23-25]. In addition, the ethyl acetate extract of T. nilotica

*Corresponding author: Nabila Al-Jaber, Chemistry Department, College of Science, King Saud University, Riyadh, KSA, Tel: 00966500086198; E-mail: njaber@ksu.edu.sa

Received April 01, 2017; Accepted April 14, 2017; Published April 19, 2017

Citation: Al-Jaber N, Allehaib L (2017) The Pharmacological Activity of Some Tamaricaceae Plants. Nat Prod Chem Res 5: 262. doi: 10.4172/2329-6836.1000262

Copyright: (c) 2017 Al-Jaber N, et al. This is an open-access article distributed under the terms of the Creative Commons Attribution License, which permits unrestricted use, distribution, and reproduction in any medium, provided the original author and source are credited. 
showed effective radical scavenging and cytotoxic activities. More recently, it was reported that the ethyl acetate fraction contains bioactive compounds worthy of more sophisticated studies as free radical scavenger and cytotoxic agent [17]. A previous study on the antiviral screening of forty-two Egyptian medicinal plant species revealed that the T. nilotica has virucidal effect against herpes simplex virus (HSV) [26]. The methanolic floral extract of the T. gallica exhibited antibacterial activity against Staphylococcus epidermidis, Staphylococcus aureus, Micrococcus luteus, Escherichia coli, and Pseudomonas aeruginosa; and showed antifungal activity against Candida spp. [27]. In addition, the methanolic extract from aerial parts of T. gallica possesses both antiinflammatory and analgesic effects comparable to that of non-steroidal drugs such as diclofenac and aspirin respectively [28].

Previous studies revealed that the T. gallica has a potent chemopreventive agent which may suppress thioacetamide (TAA)mediated hepatic oxidative stress, toxicity, and early tumor promotion response in rats [29]. Moreover, other studies showed that the flowers extract of T. gallica displayed a higher antioxidant activity as compared to the leaves, which could be attributed to its highest total phenolic content. In addition, T. gallica extracts showed appreciable antibacterial properties against human pathogenic strains [11]. Moreover, the $n$-butanol extract of the aerial parts of T. gallica showed an antimicrobial activity [15].

The $T$. ramosissima showed antioxidant and antimicrobial activities [8]. The methanolic extract of the leaves of $T$. indica showed antinociceptive, antidiarrhoeal and cytotoxic activities [30]. Furthermore, the methanolic extract of the roots showed antinociceptive, anti-inflammatory and antibacterial activities [31]. It has been recently reported that the crude extract and some fractionated samples of the $T$. dioica has significant antifungal properties, but low antibacterial response and negligible cytotoxic activity [32]. The leaves extract and fractions of the T. pauciovulata showed an antioxidant activity. Therefore, and according to what have been presented in the before mentioned discussions, these extracts are substantially effective in preventing diseases caused by the overproduction of radicals. They can also function as an important source of dietary supplement with health protective potential [33]. Alcoholic extract of T. macrocarpa showed an antimicrobial activity against Staphylococcus aureus, Bacillus subtilis, and Candida albicans at a level of $1000 \mathrm{mcg} / \mathrm{mL}$ [34]. The flavonoids extracted from $T$. chinensis showed an effective antioxidant activity [35]. In conclusion, this literature review indicated that there was lack of studies of $T$. aucheriana with regard to chemical constituents and biological activities compared with T. nilotica, and T. aphylla.

\section{Materials and Methods}

\section{Materials}

Animals: Wistar albino male rats (150-180 g) and Swiss albino mice (25-30 g) were used for studying pharmacology. They both were obtained from a Lab Animal Care Unit, Pharmacy College, Salman Bin Abdulaziz University, Al-Kharj, KSA. All animals were housed in polyacrylic cages (two animals per cage) and were kept under constant environmental conditions in the laboratory (temperature $24-26^{\circ} \mathrm{C}$, relative humidity, $60-70 \%$ and $12 \mathrm{~h}$ light- dark cycles) and fed commercial rodent diet and water ad libitum. They were allowed for one week to acclimate for the work area environment before use. All experiments involving animals were done according to the internationally accepted standard guidelines and were approved by an institutional review board.

Preparation of the extracts for in vivo studies: The standard drugs (acetyl salicylic acid, indomethacin, and paracetamol) and the total alcoholic extracts of the T. aucheriana, T. nilotica, and T. aphylla were suspended separately in 3\% v/v Tween 80 (vehicle).

\section{Methods}

Acute toxicity $\left(\mathbf{L D}_{50}\right)$ test: The Swiss albino mice were divided into equal groups, in which each group consists of 6 mice (4 groups/ extract). The control group received the vehicle and was kept without any treatment. The mice groups were orally given the three plant extracts in graded doses from 1000 to $4000 \mathrm{mg} / \mathrm{kg}$ b.wt. The mice were observed for $48 \mathrm{~h}$, in which toxic symptoms and number of died mice were noted in each group. The oral median lethal doses $\left(\mathrm{LD}_{50}\right)$ of the alcoholic extracts of T. aucheriana, T. nilotica, and the T. aphylla were calculated mathematically according to the method described by Gad and Weil [36].

Doses: In this study, the doses of alcoholic extracts for T. aucheriana, T. nilotica, and the T. aphylla were determined in the acute toxicity study, which showed on toxic effect of oral administration in doses up to 4000 $\mathrm{mg} / \mathrm{kg}$. Accordingly, the experimental doses of $400 \mathrm{mg} / \mathrm{kg}$ that equal $1 / 10$ of the maximum possible dose of the tested extracts that did not cause mortalities in mice were selected to be given orally. The standard drug; indomethacin, acetyl salicylic acid, and paracetamol were given orally at doses of $(5,200$, and $150 \mathrm{mg} / \mathrm{kg}$, respectively) according to the table of Paget and Barnes [37].

Sub-chronic toxicity: Wistar albino rats were randomly divided into 4 groups, in which each group consists of six rats. The rats of the $1^{\text {st }}$ group (control) received the vehicle $(5 \mathrm{~mL} / \mathrm{kg}$ ) and were kept without any treatment. The rats of the $2^{\text {nd }}, 3^{\text {rd }}$, and $4^{\text {th }}$ groups; on the other hand, were orally given the alcohol extracts of the T. aucheriana, T. nilotica, and T. aphylla, respectively in a dose of $(400 \mathrm{mg} / \mathrm{kg})$, and were administered for 35 days on a daily basis with close observation. All rats were maintained under identical conditions and they were provided with food and water for the entire observation period. At the end of the experimental period, the blood samples $(2 \mathrm{~mL})$ were collected by puncturing the retro-orbital venous sinus of each rat. The blood samples were then centrifuged at 10,000 rpm for 5 minutes. After that, the sera were separated to be used for the biochemical analysis.

Measurement of liver and kidney function markers: The liver functions were evaluated by measuring the serum activity of alanine aminotransferase (ALT) and aspartate aminotransferase (AST) according the method of Reitman and Frankel [38]. In addition, the serum levels were assayed of the total bilirubin [39].

The kidney functions, on the other hand, were measured by determining the serum concentrations of urea (Wills and Savory) and creatinine [40] calorimetrically.

Anti-inflammatory activity: The carrageenan - induced paw edema method [41] was utilized to assess the anti-inflammatory activity of the T. aucheriana, T. nilotica, and T. aphylla extracts. The edema was expressed as an increase in paw volume. The rats were divided into five groups, in which each group consists of six rats. The rats of the $1^{\text {st }}$ group (control) received the vehicle $\left(0.5 \%\right.$ of Tween 80 p.o.). The $2^{\text {nd }}$ group (standard reference) was treated orally with the aqueous solution of indomethacin $(5 \mathrm{mg} / \mathrm{kg})$. The rats of the $3^{\text {rd }}, 4^{\text {th }}$, and $5^{\text {th }}$ groups were orally given the total alcohol extracts of the T. aucheriana, T. nilotica, and T. aphylla, respectively in a dose of $(400 \mathrm{mg} / \mathrm{kg})$. After 30 minutes, the paw edema (acute inflammation) was induced by the sub-plantar injection of $0.1 \mathrm{~mL}$ of $1 \% \lambda$-carrageenan in $0.9 \%$ of saline, in the left hind paw of all of the rats. The edema volumes were determined in $(\mathrm{mL})$ using a plethysmometer (model 7140, Ugo Basile, Italy) $3 \mathrm{~h}$ after a 
carrageenan injection. The percentage reduction of the paw edema was calculated for each group using the following formula:

$$
\text { Reduction of edema }(\%)=\frac{E v(\text { Control })-E v(\text { Test })}{E v(\text { Control })} \times 100
$$

Where, Ev is the edema volume $(\mathrm{mL})$.

Antinociceptive activity: The analgesic activity of the alcoholic extracts of the T. aucheriana, T. nilotica, and T. aphylla were implemented in the Swiss albino mice by using acetic acid induced writhing and hot plate methods.

Acetic acid-induced writhing method: The peripheral analgesic activity of the alcoholic extracts for the T. aucheriana, T. nilotica, and T. aphylla were measured by using acetic acid-induced writhing method [42]. The mice were then divided into five groups, in which each group consists of six animals. The mice of the $1^{\text {st }}$ (control) and $2^{\text {nd }}$ (standard) groups were treated orally with the vehicle and acetyl salicylic acid (200 $\mathrm{mg} / \mathrm{kg}$ ), respectively. On the other hand, the mice of the $3^{\text {rd }}, 4^{\text {th }}$, and $5^{\text {th }}$ groups were treated orally with the total alcohol extracts of the $T$. aucheriana, T. nilotica, and T. aphylla, respectively in a dose of $(400$ $\mathrm{mg} / \mathrm{kg}$ ). The writhing in mice was induced one hour later of treated, by injection of glacial acetic acid $(0.6 \%, 10 \mathrm{ml} / \mathrm{kg}$, i.p.). The number of writhes was calculated for each animal for $20 \mathrm{~min}$, after ten min from the acetic acid injection. The responses of the treated groups with the extracts and acetyl salicylic acid were compared with those of the animals in the control group. The analgesic activity was expressed as the percentage protection against writhing (\% inhibition of writhing) and it was calculated as follows:

$$
\text { Inhibition }(\%)=\frac{W t(\text { Control })-W t(\text { Test })}{W t(\text { Control })} \times 100
$$

where, Wt is mean number of writhing.

Hot plate method: The analgesic activity of the alcoholic extracts of the T. aucheriana, T. nilotica, and T. aphylla were measured in the Swiss albino mice by using Eddy's hot plate method [43]. The mice were then divided into 5 groups, in which each group consists of six animals. The mice of the $1^{\text {st }}$ (control) and $2^{\text {nd }}$ (standard) groups were orally administered with the vehicle $(10 \mathrm{~mL} / \mathrm{kg})$ and acetyl salicylic acid $(200 \mathrm{mg} / \mathrm{kg})$, respectively. The mice of the $3^{\text {rd }}, 4^{\text {th }}$, and $5^{\text {th }}$ groups were treated orally with the total alcohol extracts of the T. aucheriana, T. nilotica, and T. aphylla, respectively in a dose of $(400 \mathrm{mg} / \mathrm{kg})$. Mice were individually placed into a transparent glass cylinder (diameter 20 $\mathrm{cm}$ ) on the hot plate (Ugo basil Italy, socrel and model DS-37) and were maintained at $55^{\circ} \mathrm{C}$ to induce pain. The reaction time of each mouse for (licking of hind paw or jumping) were recorded with a cut-off time of seconds, and then the measurement was terminated when exceeded the latency period $(20 \mathrm{sec})$ in order to avoid injury. The latency period of twenty secs was defined as a complete analgesia. The nociceptive response (in seconds) was measured at 1,2 , and $3 \mathrm{~h}$ after the treatment.

Antipyretic activity: The antipyretic activity of the alcoholic extracts for the T. aucheriana, T. nilotica, and T. aphylla were measured in the Wistar albino male rats (150-180 g) by using a yeast-induced hyperpyrexia test [44]. Pyrexia was induced in the rats by subcutaneous injection of brewer's yeast $(10 \mathrm{ml} / \mathrm{kg}, 20 \% \mathrm{w} / \mathrm{v}$ in distilled water). Basal rectal temperature was measured before and eighteen $\mathrm{h}$ after the injection of yeast, by inserting a digital clinical thermometer to a depth of $2 \mathrm{~cm}$ into the rectum. The febrile rats were divided into five groups (six animals in each group). The rats of the $1^{\text {st }}$ group (control) received the vehicle ( $0.5 \%$ of Tween 80 p.o.) while the $2^{\text {nd }}$ group (standard) was orally given the aqueous solution of paracetamol in a dose of $(150 \mathrm{mg} /$ $\mathrm{kg}$ ). The rats of the $3^{\text {rd }}, 4^{\text {th }}$, and $5^{\text {th }}$ groups were treated orally with the total alcohol extracts for the T. aucheriana, T. nilotica, and T. aphylla, respectively in a dose of $(400 \mathrm{mg} / \mathrm{kg})$. After that, the rectal temperature of each rat was recorded at one-hour interval after treatment for four hour.

Statistical analysis: All parametric values are given as Mean \pm SEM and were analyzed using One-way ANOVA followed by Student Newman-Keuls test which revealed a significance at $p<0.05$.

\section{Results}

\section{Acute toxicity $\left(\mathrm{LD}_{50}\right)$}

The obtained results indicated that the mice treated with alcoholic extracts for the T. aucheriana, T. nilotica, and T. aphylla in different doses $(1000-4000 \mathrm{mg} / \mathrm{kg}$ ) showed not symptoms of acute toxicity; diarrhea, hematuria, restlessness, uncoordinated muscle movements, or respiratory distress. In addition, the mice were alive during the whole $48 \mathrm{~h}$ of observation. Accordingly, it is suggested that the oral median lethal doses $\left(\mathrm{LD}_{50}\right)$ of the alcoholic extracts of the three plants were higher than $4000 \mathrm{mg} / \mathrm{kg}$ [45].

\section{Sub-chronic toxicity (liver and kidney function)}

The obtained results (Table 1) showed that the oral administration of the alcoholic extracts for T. aucheriana, T. nilotica, and T. aphylla in a dose of $400 \mathrm{mg} / \mathrm{kg}$ for 35 days to rats did not show any significant effect on the serum activity of ALT and AST and serum level of total bilirubin as opposed to the control group. An exception of the effect of T. aphylla extract on serum activity of ALT was found, which showed a significant effect $(\mathrm{p}<0.05)$ when compared to the control group.

On the other hand, the obtained results (Table 2) did not show any significant change in the mean values of urea and creatinine in sera of rats that were treated orally of the tested extracts in a dose at $400 \mathrm{mg} / \mathrm{kg}$ for 35 days as opposed to the control group.

\section{Anti-inflammatory activity}

The anti-inflammatory activity of the alcoholic extracts for the $T$. aucheriana, T. nilotica, and T. aphylla were evaluated against acute paw edema induced by carrageenan (Table 3). The carrageenan-induced inflammation in the rat paw represents a classical model of acute inflammation that was used for the assessment of the anti-inflammatory activity of the standard drugs and extracts. The mean changes in paw edema at $3 \mathrm{~h}$ after carrageenan administration for the (control group) was $0.97 \pm 0.04 \mathrm{~mL}$. The standard drug; indomethacin $(5 \mathrm{mg} / \mathrm{kg})$ and the total alcohol extracts $(400 \mathrm{mg} / \mathrm{kg})$ of the T. aucheriana, T. nilotica, and T. aphylla produced a significant reduction of carrageenan-induced paw edema $(0.23 \pm 0.01 \mathrm{ml}, 0.86 \pm 0.04 \mathrm{~mL}, 0.87 \pm 0.03 \mathrm{~mL}$, and $0.37 \pm$ $0.01 \mathrm{~mL}$, respectively) as opposed to the control rats. The percentages of the reduction of paw edema for the T. aucheriana, T. nilotica, and T.

\begin{tabular}{|c|c|c|c|}
\hline Groups & $\begin{array}{c}\text { ALT } \\
(\mathbf{U} / \mathbf{~ m l})\end{array}$ & $\begin{array}{c}\text { AST } \\
\mathbf{( U / ~} \mathbf{~ m l})\end{array}$ & $\begin{array}{c}\text { Total Bilirubin } \\
\text { (mg/ dl) }\end{array}$ \\
\hline Control & $39.22 \pm 1.57$ & $71.50 \pm 2.16$ & $0.46 \pm 0.025$ \\
\hline T. aucheriana & $46.85 \pm 3.26$ & $77.35 \pm 2.43$ & $0.53 \pm 0.042$ \\
\hline T. nilotica & $41.25 \pm 2.29$ & $70.72 \pm 3.38$ & $0.48 \pm 0.035$ \\
\hline T. aphylla & $48.12 \pm 3.15^{\star}$ & $80.31 \pm 3.50$ & $0.51 \pm 0.033$ \\
\hline
\end{tabular}

Significant at ${ }^{*} \mathrm{p}<0.05$ : Values are Mean \pm SEM.

Table 1: Effect of prolonged oral administration of the tested extracts in a dose of $400 \mathrm{mg} / \mathrm{kg}$ for 35 consecutive days on the serum activity of ALT and AST and serum levels of total bilirubin in rats $(n=6)$. 
Citation: Al-Jaber N, Allehaib L (2017) The Pharmacological Activity of Some Tamaricaceae Plants. Nat Prod Chem Res 5: 262. doi: 10.4172/23296836.1000262

Page 4 of 6

\begin{tabular}{|c|c|c|}
\hline Groups & $\begin{array}{c}\text { Urea } \\
\text { (mg/ dl) }\end{array}$ & $\begin{array}{c}\text { Creatinine } \\
(\mathbf{m g} / \mathbf{d l})\end{array}$ \\
\hline Control & $21.50 \pm 0.96$ & $0.41 \pm 0.032$ \\
\hline T. aucheriana & $22.58 \pm 0.91$ & $0.44 \pm 0.031$ \\
\hline T. nilotica & $20.76 \pm 1.21$ & $0.41 \pm 0.027$ \\
\hline T. aphylla & $23.64 \pm 0.84$ & $0.43 \pm 0.024$ \\
\hline
\end{tabular}

Table 2: Effect of prolonged oral administration of the tested extracts in a dose of $400 \mathrm{mg} / \mathrm{kg}$ for 35 consecutive days on the serum concentrations of urea and creatinine in rats $(n=6)$.

\begin{tabular}{|c|c|c|c|}
\hline Treatments & Dose (mg/kg) & $\begin{array}{c}\text { Mean Changes in Paw Edema }(\mathrm{ml}) 3 \mathrm{~h} \text { After Carrageenan } \\
\text { Administration }\end{array}$ & Reduction of Paw Edema (\%) \\
\hline Control & 00 & $0.97 \pm 0.04$ & - \\
\hline Indomethacin & 5 & $0.23 \pm 0.01^{\star}$ & 76.28 \\
\hline T. aucheriana & 400 & $0.86 \pm 0.04$ & 11.34 \\
\hline T. nilotica & 400 & $0.87 \pm 0.03$ & 10.30 \\
\hline T. aphylla & 400 & $0.37 \pm 0.01^{\star}$ & 61.85 \\
\hline
\end{tabular}

Significant at * $p<0.05$ : Values are Mean \pm SEM.

Table 3: Evaluation of anti-inflammatory effect of the T. aucheriana, T. nilotica, and T. aphylla extracts on carrageenan-induced paw edema in rats.

\begin{tabular}{|c|c|c|c|}
\hline Treatments & Dose $\mathbf{( m g / k g )}$ & Number of Writhing Over a Period of 20 min & \% Inhibition of Writhing \\
\hline Control & 00 & $36.50 \pm 2.17$ \\
\hline Acetyl Salicylic acid & 200 & $20.66 \pm 1.08^{*}$ \\
\hline T. aucheriana & 400 & $35.33 \pm 0.49$ \\
\hline T. nilotica & 400 & $35.50 \pm 0.84$ & 3.39 \\
\hline T. aphylla & 400 & $24.16 \pm 0.60^{*}$ \\
\hline
\end{tabular}

Significant at ${ }^{*} p<0.05$ : Values are Mean \pm SEM.

Table 4: Evaluation of analgesic effect of the T. aucheriana, T. nilotica and T. aphylla extracts by writhing method in mice.

\begin{tabular}{|c|c|c|c|c|}
\hline \multirow{2}{*}{ Treatments } & \multirow{2}{*}{ Dose (mg/kg) } & \multicolumn{3}{|c|}{ Hot Plate Reaction Time (sec) } \\
\hline & & $1 \mathrm{~h}$ & $2 \mathrm{~h}$ & $3 \mathrm{~h}$ \\
\hline Control & 00 & $10.52 \pm 0.50$ & $10.44 \pm 0.67$ & $10.84 \pm 0.73$ \\
\hline Acetyl Salicylic acid & 200 & $16.78 \pm 0.51^{*}$ & $17.17 \pm 0.28^{*}$ & $17.36 \pm 0.48^{*}$ \\
\hline T. aucheriana & 400 & $10.37 \pm 0.45$ & $10.09 \pm 0.28$ & $9.87 \pm 0.43$ \\
\hline T. nilotica & 400 & $10.15 \pm 0.48$ & $10.51 \pm 0.36$ & $10.24 \pm 0.38$ \\
\hline T. aphylla & 400 & $15.02 \pm 0.49^{*}$ & $15.17 \pm 0.49^{*}$ & $15.37 \pm 0.81^{*}$ \\
\hline
\end{tabular}

Significant at ${ }^{*} p<0.05$ : Values are Mean \pm SEM.

Table 5: Evaluation of analgesic effect of the T. aucheriana, T. nilotica, and T. aphylla extracts by Eddy's hot plate method in mice.

\begin{tabular}{|c|c|c|c|c|c|c|}
\hline \multirow{2}{*}{ Treatments } & \multirow{2}{*}{ Dose $(\mathrm{mg} / \mathrm{kg})$} & \multirow{2}{*}{$\begin{array}{l}\text { Rectal Temperature }\left({ }^{\circ} \mathrm{C}\right) 16 \mathrm{~h} \\
\text { after Yeast Injection }\end{array}$} & \multicolumn{4}{|c|}{ Mean Rectal Temperature $\left({ }^{\circ} \mathrm{C}\right)$ after Treatment } \\
\hline & & & $1 \mathrm{~h}$ & $2 \mathrm{~h}$ & $3 \mathrm{~h}$ & 4h \\
\hline Control & 00 & $39.28 \pm 0.30$ & $39.63 \pm 0.29$ & $39.50 \pm 0.33$ & $39.80 \pm 0.29$ & $39.20 \pm 0.22$ \\
\hline Paracetamol & 150 & $39.86 \pm 0.32$ & $37.91 \pm 0.26^{*}$ & $37.76 \pm 0.18^{*}$ & $38.01 \pm 0.33^{*}$ & $38.70 \pm 0.29$ \\
\hline T. aucheriana & 400 & $39.61 \pm 0.37$ & $39.16 \pm 0.52$ & $39.30 \pm 0.40$ & $39.20 \pm 0.42$ & $39.03 \pm 0.40$ \\
\hline T. nilotica & 400 & $39.35 \pm 0.33$ & $39.13 \pm 0.40$ & $39.16 \pm 0.47$ & $39.18 \pm 0.42$ & $39.48 \pm 0.30$ \\
\hline T. aphylla & 400 & $39.53 \pm 0.40$ & $39.15 \pm 0.46$ & $38.98 \pm 0.31$ & $39.15 \pm 0.37$ & $39.00 \pm 0.42$ \\
\hline
\end{tabular}

Significant at " $p<0.05$ : Values are Mean \pm SEM.

Table 6: Evaluation of antipyretic effect of the T. aucheriana, T. nilotica, and T. aphylla extracts by yeast-induced pyrexia in rats.

aphylla extracts were found to be less than that of the standard drug. The highest anti-inflammatory effect was recorded with the alcoholic extract of T. aphylla with (61.85\%) paw edema reduction.

\section{Antinociceptive activity}

The antinociceptive activity of the alcoholic extracts for the $T$. aucheriana, T. nilotica, and T. aphylla were measured by using two methods: the acetic acid induced writhing and the hot plate method.

Table 4 however, showed an analgesic effect of the acetyl salicylic acid and the tested extracts by using writhing method in mice. The number of writhing over a period of twenty min after acetic acid injection of the control group was $36.50 \pm 2.17$. The standard drug; acetyl salicylic acid $(200 \mathrm{mg} / \mathrm{kg})$ and the total alcohol extract $(400 \mathrm{mg} / \mathrm{kg})$ of the $T$. aphylla produced significant reduction of the number of writhing in mice $(20.66 \pm 1.08$ and $24.16 \pm 0.60$, respectively). On the other hand, the total alcohol extracts of the T. aucheriana, and T. nilotica produced some reduction $(35.33 \pm 0.49$ and $35.50 \pm 0.84$, respectively) as opposed to the control animals. The percentage protection against writhing produced by the tested extracts was less than that of the standard drug. The alcohol extract of T. aphylla showed the highest analgesic activity (33.80\% inhibition) as opposed to the extracts of the T. aucheriana, and T. nilotica (3.20\% and $2.73 \%$ inhibition, respectively).

Table 5 showed an analgesic effect of the standard drug and the 
tested extracts by using Eddy's hot plate method. The alcohol extract of T. aphylla and the standard drug showed a significant analgesic activity as evidenced by significant increase in reaction time when compared with the control animals. However, analgesic activity of the T. aphylla extract were less than that of the standard drug.

\section{Antipyretic activity}

The antipyretic activity of the alcoholic extracts for the T. aucheriana, T. nilotica, and T. aphylla were measured by using yeast-induced pyrexia in rats (Table 6). The alcoholic extracts of the T. aucheriana, T. nilotica, and T. aphylla did not show any antipyretic activity as opposed to the standard drug (Paracetamol).

\section{Aknowledgment}

This research project was supported by a grant from the "Research Center of the Female Scientific and Medical Colleges", Deanship of Scientific Research, King Saud University.

\section{References}

1. Orfali RS, Ebada SS, El-Shafae AM, Al-Taweel AM, Lin WH, et al. (2009) 3-O-trans-caffeoylisomyricadiol: A New Triterpenoid from Tamarix nilotica Growing in Saudi Arabia. Z Naturforsch C 64: 637-643.

2. Migahid A (1988) Flora of Saudi Arabia. 3rd edn. Riyadh: University Libraries, King Saud University, pp: 91-92.

3. Gaskin JF, Shafroth PB (2005) Hybridization of Tamarix ramosissima and $T$. chinensis (Saltcedars) with $T$. aphylla (Athel) (Tamaricaceae) in the Southwestern USA Determined from DNA Sequence Data. Madrono 52: 1-10.

4. Chaudhary SA (2001) Flora of the Kingdom of Saudi Arabia Illustrated Riyadh. Ministry of Agriculture \& Water, National Herbarium, National Agriculture and Water Research Center. 1: 405-408.

5. Ghazanfar SA (1994) Handbook of Arabian Medicinal Plants. 1st edn. Boca Raton, FL: CRC Press. pp: 203-204.

6. Saidana D, Mahjoub MA, Boussaada O, Chriaa J, Che'raif I, et al. (2008) Chemical Composition and Antimicrobial Activity of Volatile Compounds of Tamarix boveana (Tamaricaceae). Microbiological Research 163: 445-455.

7. Sultanova NA, Abilov ZhA, Omurkamzinova VB, Chaudri IM (2002) Flavonoids of The Aerial Part of Tamarix hispida. Chemistry of Natural Compounds 38: 98-99.

8. Sultanova N, Makhmoor T, Abilov ZA, Parween Z, Omurkamzinova VB, et al. (2001) Antioxidant and Antimicrobial Activities of Tamarix ramosissima. J Ethnopharmacology 78: 201-205.

9. Mohammedi Z, Atik F (2011) Impact of Solvent Extraction Type on Total Polyphenols Content and Biological Activity from Tamarix aphylla (I.) Karst. International Journal of Pharma \& Bio Sciences 2: 609-615.

10. Zain ME, Awaad AS, Al-Outhman MR, El-Meligy RM (2012) Antimicrobial Activities of Saudi Arabian Desert Plants. Phytopharmacology 2: 106-113.

11. Ksouri R, Falleh H, Megdiche W, Trabelsi N, Mhamdi B, et al. (2009) Antioxidant and Antimicrobial Activities of the Edible Medicinal Halophyte Tamarix gallica L. and Related Polyphenolic Constituents. Food and Chemical Toxicology 47: 2083-2091.

12. Jaganath I, Crozier A (2009) Dietary Flavonoids and Phenolic Compounds. In: Fraga C (eds.), Plant Phenolics and Human Health: Biochemistry, Nutrition and Pharmacology. 1st edn. Hoboken, NJ: John Wiley and Sons Inc., p: 21.

13. Parmar VS, Bisht KS, Sharma SK, Jain R, Taneja P, et al. (1994) Highly Oxygenated Bioactive Flavones from Tamarix. Phytochemistry 36: 507-511.

14. Sultanova N, Makhmoor T, Yasin A, Abilov ZA, Omurkamzinova VB, et al. (2004) Isotamarixen- A New Antioxidant and Prolyl Endopeptidase-Inhibiting Triterpenoid from Tamarix hispida. Planta Med 70: 65-67.

15. Lefahal M, Benahmed M, Louaar S, Zallagui A, Duddeck H, et al. (2010) Antimicrobial Activity of Tamarix gallica L. Extracts and Isolated Flavonoids. Advances in Natural and Applied Sciences 4: 289-292.

16. Nawwar MAM, Buddrus J, Bauer H (1982) Dimeric Phenolic Constituents from the Roots of Tamarix nilotica. Phytochemistry 21: 1755-1758.

17. Bakr RO, El-Raey MA, Ashour RS (2013) Phenolic Content, Radical Scavenging
Activity and Cytotoxicity of Tamarix nilotica (Ehrenb.) Bunge Growing in Egypt. Journal of Pharmacognosy and Phytotherapy 5: 47-52.

18. Yusufoglu HS, Al-qasoumi SI (2011) Anti-inflammatory and Wound Healing Activities of Herbal Gel Containing an Antioxidant Tamarix aphylla Leaf Extract. International Journal of Pharmacology 7: 829-835.

19. Kamal M, Wazir SM, Hassan M, Subhan M, Khan SU, et al. (2009) Ethnobotanically Important Plants of District Bannu, Pakistan. Pak J Plant Sci 15: 87-93.

20. AbouZid S, Sleem A (2011) Hepatoprotective and Antioxidant Activities of Tamarix nilotica Flowers. Pharm Biol 49: 392-395.

21. Nawwar MAM, Hussein SAM, Ayoub NA, Hofmann K, Linscheid M, et al. (2009) Aphyllin, The First Isoferulic acid Glycoside and Other Phenolics from Tamarix aphylla Flowers. Pharmazie 64: 342-347.

22. Barakat HH, Nada SA (1996) Chemical and Biological Investigations of the Constitutive Phenolics of Two Egyptian Folk-Medicinal Plants; A Novel Phenolic from the Galls of Tamarix aphylla. Natural product sciences 2: 96-101.

23. AbouZid S, Elshahaat A, Ali S, Choudhary MI (2008) Antioxidant Activity of Wild Plants Collected in Beni-Sueif Governorate, Upper Egypt. Drug Discov Ther 2: 286-288.

24. AbouZid S (2013) Chemical and Biological Studies on Tamarix nilotica Growing in Egypt. Planta Medica 79: 13.

25. AbouZid SF, Ali SA, Choudhary MI (2009) A New Ferulic Acid Ester and Other Constituents from Tamarix nilotica Leaves. Chem Pharm Bull 57: 740-742.

26. Soltan MM, Zaki AK (2009) Antiviral Screening of Forty-Two Egyptian Medicinal Plant. Journal of Ethnopharmacology 126: 102-107.

27. Voon HC, Bhat R, Rusul G (2012) Flower Extracts and their Essential Oils as Potential Antimicrobial Agents for Food Uses and Pharmaceutical Applications. Comprehensive Reviews in Food Science and Food Safety 11: 34-55.

28. Chaturvedi S, Drabu S, Sharma M (2012) Anti- Inflammatory and Analgesic Activity of Tamarix gallica. International Journal of Pharmacy and Pharmaceutical Sciences 4: 653-658.

29. Sehrawat A, Sultana S (2006) Tamarix gallica Ameliorates ThioacetamideInduced Hepatic Oxidative Stress and Hyperproliferative Response in Wistar Rats. J Enzyme Inhib Med Chem 21: 215-223.

30. Habiba U, Bose U, Rahman AA (2010) Antinociceptive, Antidiarrhoeal and Cytotoxic Activity of Tamarix Indica Leaf. Int J Pharmacol 1: 275-283.

31. Rahman MA, Haque E, Hasanuzzaman M, Shahid IZ (2011) Antinociceptive Anti-inflammatory and Antibacterial Properties of Tamarix indica Roots. International Journal of Pharmacology 7: 527-531.

32. Khan S, Ullah F, Mahmood T (2013) In Vitro Antimicrobial and Cytotoxic Activity of Tamarix dioica Roxb. Leaves. Turk J Biol 37: 329-335.

33. Mohammedi Z, Atik F (2012) HPLC-UV Analysis and Antioxidant Potentia of Phenolic Compounds from Endemic Shrub of Arid Environment Tamarix pauciovulata. J Gay Journal of Life Sciences 6: 883-891.

34. Al-Shamma AA, Kadhum EJ, Al-Hiti MMA (2006) Antimicrobial Activity and Phytochemical Investigation of Tamarix macrocarpa (Ehrenb.) Bge Wildly Grown in Iraq. Iraqi Journal of Pharmaceutical Sciences 15: 99-104.

35. Qu Y, Tong G, Wang B, Yang L (2011) Optimized Microwave-Assisted Extraction of Flavonoids from Tamarix chinensis and Evaluation of Antioxidant Activity in Vitro. Remote Sensing, Environment and Transportation Engineering (RSETE) 2011 International Conference 7697-7700.

36. Gad SC, Weil CS (1982) Statistics for Toxicologists. In: Hayes AW (ed.) Principles and Methods of Toxicology, New York: Raven Press, pp: 273-320.

37. Paget GE, Barnes JM (1964) Toxicity Tests. In: Laurence DR, Bacharach AL (eds.), Evaluation of Drug Activities: Pharmacometrics. London and New York: Academic Press, pp: 135-166.

38. Reitman S, Frankel S (1957) Colorimetric Methods for Aspartate and Alanine Aminotransferases. American Journal of Clinical Pathology 28: 55-60.

39. Walter MI, Gerarde HW (1970) An Ultramicromethod for the Determination of Conjugated and Total Bilirubin in Serum or Plasma. Microchemistry Journal 15: 231-243.

40. Kroll MH, Roach NA, Poe B, Elin RJ (1987) Mechanism of Interference with Jaffe Reaction for Creatinine. Clinical Chemistry 33: 1129-1132. 
Citation: Al-Jaber N, Allehaib L (2017) The Pharmacological Activity of Some Tamaricaceae Plants. Nat Prod Chem Res 5: 262. doi: 10.4172/23296836.1000262

41. Winter CA, Risely EA, Nuss GV (1962) Carrageenan-Induced Oedema in Hind Paw of the Rat as an Assay for Anti-inflammatory Drugs. Proc Soc Exp Biol Med 111: 544-547.

42. Koster R, Anderson M, Debber EJ (1959) Acetic acid for Analgesics Screening. Federation Proceedings 18: 412-417.

43. Loux JJ, Depalma PD, Yankell SL (1972) Antipyretic Testing of Aspirin in Rats. Toxicology and applied pharmacology 22: 672-675.
44. Eddy NB, Leimbach D (1953) Synthetic Analgesics. II. Dithienylbutenyl- and Dithienylbutylamines. J Pharmacol Exp Ther 107: 385-393.

45. Awaad A, El-Meligy R, Qenawy S, Atta A, Soliman G (2011) Anti-inflammatory, Antinociceptive and Antipyretic Effects of some Desert Plants. Journal of Saud Chemical Society 15: 367-373. 